\title{
PENINGKATAN KUALITAS GERABAH MELALUI PENGOLAHAN DAN PENYARINGAN BAHAN DI SANDI KECAMATAN PATTALLASSANG KABUPATEN TAKALAR
}

\author{
Jalil Saleh, Irfan, Irfan Arifin \\ Fakultas Seni dan Desain Universitas Negeri Makassar \\ jalil@unm.ac.id \\ irfanridh@unm.ac.id \\ irfan.arifin@unm.ac.id
}

\begin{abstract}
Abstrak
Kabupaten Takalar merupakan salah satu daerah penghasil seni gerabah tradisional yang masih bertahan sampai saat ini, namun demikian, para perajin belum mampu menghasilkan gerabah yang berkualitas baik dan bisa bernilai kompetitif di pasar global. "Umega Gerabah" merupakan salah satu kelompok perajin yang telah mengembangkan desain, bentuk dan ragam hias gerabah menjadi lebih modern. Beberapa permasalahan yang dialami adalah kualitas body gerabah masih gampang pecah/retak khususnya saat proses pembakaran, masih sulit menerapkan teknik hias toreh secara detail pada body gerabah, serta kualitas gerabah belum bisa dikembangkan pada tahap teknik glasir. Masalah lainnya adalah system pemasaran masih tradisional dan belum memanfaatkan media internet. Berdasarkan identifikasi dan penelitian awal, beberapa penyebabnya adalah kualitas bahan baku tanah liat yang kurang plastis, masih banyak campuran pasir, serta teknik pengolahan masih secara manual, diinjak-injak lalu diulet dan dibentuk. Solusi yang ditawarkan adalah menggunakan alternatif bahan baku dari daerah lain, mencampur tanah liat asli dari daerah perajin gerabah di Takalar dengan tanah liat dari daerah lain dengan teknik pengolahan secara masinal (menggunakan ball mill atau mixer) atau menyaring tanah dengan baik agar memiliki kualitas yang lebih baik daripada tanah asli Takalar yang hanya diolah secara tradisional. Untuk solusi pemasaran akan dibuatkan media sosial online seperti Instagram, dan lainnya yang dapat digunakan untuk mempromosikan produk gerabah dari Takalar. Luaran yang telah dicapai adalah seluruh mitra yang ikut pelatihan memiliki keterampilan menyaring tanah, 3 diantaranya telah menerapkan teknik saring untuk memproduksi pesanan pembeli. Hasil pembekaran gerabah yang dibuat dengan bahan yang disaring dapat mengurangi keretakan body hingga 28\%. Luaran publikasi adalah video dan berita kegiatan yang telah di publikasi pada media massa online.
\end{abstract}

Kata Kunci: Gerabah, Bahan baku, Penyaringan

\section{PENDAHULUAN}

Keramik sebagai produk budaya, merupakan perwujudan ide, teknologi, nilai, maupun norma yang dianut oleh masyarakat tertentu. Setiap daerah memiliki bentuk keramik yang khas dan berbeda dengan daerah lainnya, baik dari aspek teknik pembuatan, gaya dan ciri khasnya masingmasing [1]. Kabupaten Takalar Sulawesi Selatan memiliki tiga kecamatan yang menjadi sentra industri gerabah, yaitu Kecamatan Pattallassang (Sandi), Kecamatan Mappakasunggu (Pa'batangan) dan Kecamatan Sanrobone (Pakalli). Berdasarkan data statistik Kabupaten Takalar Pada tahun
2015 di Pattallassang terdapat sekitar 120 unit usaha gerabah yang melibatkan perajin sekitar 380 orang yang mendapatkan bimbingan dari Departemen Perindustrian dan Perdagangan kabupaten Takalar. Di Kecamatan Mappakasunggu dan Kecamatan Sanrobone terdapat sekitar 160 unit usaha gerabah yang melibatkan sekitar 520 orang perajin yang mendapatkan bimbingan dari Departemen Perindustrian dan Perdagangan Kabupaten Takalar [2]. Total unit usaha dan perajin yang terdata dan mendapatkan bimbingan dari Departemen Perindustrian dan Perdagangan Kabupaten Takalar sampai tahun 2015 di kecamatan Pattallassang, Kecamatan Mappakasunggu dan Kecamatan Sanrobone 
adalah 280 unit usaha dan 900 perajin. Sedangkan sebagian lainnya hanya menjadikan pembuatan gerabah sebagai pekerjaan sampingan selain bertani. Kabupaten Takalar pada masa lalu, khususnya warga Dusun Sandi di Patttallassang dan Desa Pa'batangan di Kecamatan Mappakasunggu bekerja sebagai perajin keramik tradisional untuk keperluan masak memasak. Perajin membentuk kelompok kecil terdiri dari 3-7 orang untuk memenuhi pesanan dan pasar tradisional dan pengumpul yang biasanya mengangkut dengan perahu [3].

Di Kecamatan Pattallassang, konsentrasi lokasi perajin terpusat di Dusun Sandi Kelurahan Pallantikan, pada tahun 2016 terdapat 40 lebih unit usaha gerabah yang berbasis kekeluargaan, kebanyakan memproduksi kursi keramik dari bahan tanah liat yang biasanya dijual dengan harga murah, hanya Rp. 150.000- Rp. 200.000 per satu shet kursi (4 kursi dan satu meja), lebih murah dari harga kursi plastik, sementara proses produksinya terlihat rumit dan melelahkan perajin. Salah satu usaha gerabah yang ada di Sandi adalah Umegah gerabah dibuka oleh $\mathrm{M}$ Yunus Dg. Siama pada tahun 2015. Usaha tersebut mulai berkembang dan semakin menawarkan banyak produk baru dan unik di tahun 2016 hingga tahun 2018, namun demikian, kelompok usaha tersebut masih mengalami kendala, masalah yang paling mengganggu adalah body keramik berupa guci gampang pecah atau retak, kurang dapat di ukir secara detail (teknik ukir basah/prabakar), serta body tidak dapat diglasir sehingga produk yang bisa dibuat terbatas hanya pada seni kerajinan gerabah dengan bakaran rendah saja. Finishing pun masih mengandalkan cat biasa dan belum ada yang diglasir.

Pemilik usaha Umegah gerabah berharap bisa membuat produk seni kerajinan keramik yang dapat diglasir sebagai salah satu alternatif untuk ditawarkan pada konsumen. Kendala yang dihadapi adalah kualitas tanah liat lokal yang kurang plastis dan kurang baik, selain itu, juga teknik pegolahan yang masih manual dengan diinjak-injak dan diulek sampai dianggap sudah plastis, selain itu, kandungan pasir yang digunakan oleh perajin pada tanah tersebut sangat banyak, sehingga membuat mutu gerabah kurang baik, kondisi ini membuat produk yang dihasilkan banyak yang retak ,khususnya produk ursi keramik maupun guci, jika membakar 20 set kursi, maka 4-6 set di antaranya mengalami keretakan. Keretakan bisa mencapai 30\% dari seluruh jumlah yang dibakar, namun produk retak ini masih bisa ditambal dengan semen, walupun demikian, permasalahan tersebut perlu diperbaiki dengan meningkatkan kualitas pengolahan bahan, maupun jenis bahan yang digunakan. Permasalahan utama gerabah Takalar adalah karena mutu bahan baku yang kurang baik, apalagi hanya diolah secara manual, sementara itu perajin juga masih malas untuk mencoba tanah liat dari luar daerah yang terbukti kualitas plastisnya lebih baik dari lempung Takalar.

Menurut perajin mitra, banyak pembeli yang mencari jenis keramik berglasir yang dibuat langsung oleh perajin di Takalar, numun, mutu bahan tanah yang kurang sesuai untuk teknik glasir, kecuali menggunakan lempung dari daerah lain. Manajemen pengelolaan usaha masih berbasis rumah tangga, dikelola sendiri dan hanya dibantu oleh anak dan keponakan dalam memproduksi seni kerajinan gerabah. Sistem pemasaran masih mengandalkan penjualan langsung di rumah/toko kecil yang dimiliki, sehingga produknya belum dikenal luas. Perajin belum memanfaatkan media sosial online untuk memasarkan produk kerajinan keramiknya.

Berdasarkan beberapa kegiatan penelitian terhadap seni kerajinan gerabah di Takalar yang pernah dilakukan, maka dapat diidentifikasi beberapa permasalahan yang dihadapi dalam proses pengembangan desain keramik di Takalar adalah. Pertama, Kualitas tanah liat yang kurang baik dan kurang bermutu. Kedua, Teknik pengolahan tanah oleh perajin masih manual sehingga lempung tidak merata pengadukannya dan membuatnya kurang plastis. Ketiga, Perajin belum berani mencoba untuk menggunakan bahan tanah liat dari luar daerah, atau mencampurkan tanah lokal dengan tanah luar sebagai bahan baku, Keempat, system pemasaran masih tradisional, belum memanfaatkan berbagai media online untuk menjual dan menawarkan barang dagangannya.

Dari berbagai permasalahan tersebut, maka sangat penting untuk Melakukan 
pendampingan dengan fokus pengembangan pada teknik pengolahan tanah liat secara masinal, mencoba tanah liat luar daerah, mencampurkan tanah liat lokal dengan tanah liat luar. Tanah liat sebagai bahan baku merupakan kunci utama dalam mengembangkan mutu gerabah Takalar, sebab mutu bahan akan menentukan kekuatan body keramik/gerabah yang dihasilkan. Selain itu, pemanfaatan bahan baku dari luar daerah perlu dilakukan guna menambah alternatif bahan yang sudah ada, dengan demikian, perajin dapat membandingkan antara tanah yang diperoleh dari daerah sekitarnya dengan tanah dari luar daerah. Pendampingan pemasaran juga perlu dilakukan, khususnya pemasaran melalui media online yang belum banyak dikenal oleh masyarakat perajin khususnya mitra.

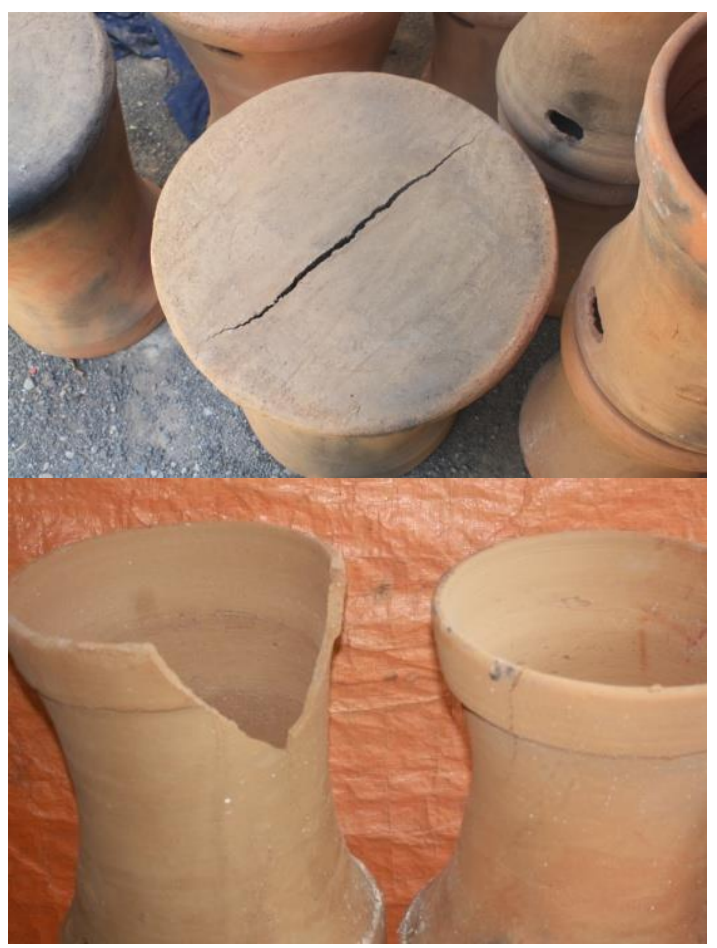

Gambar 1. Salah satu produk kursi keramik yang telah dibakar dan mengalami keretakan yang sangat lebar sebab mutu bahan yang tidak diolah dengan baik.

\section{METODE}

Metode Ceramah akan digunakan pada saat sosialisasi program dengan menjelaskan tentang jenis-jenis tanah liat dan tingkatan kualitasnya serta mengajak perajin untuk terbuka dalam hal teknologi pengolahan tanah yang lebih baik dan dapat lebih meningkatkan mutu keramik yang dibuat. Metode Demonstrasi akan dimanfaatkan dalam mendemonstrasikan teknik pengolahan tanah liat secara masinal dengan kualitas tanah yang lebih merata dan lebih plastis. Hasil pengolahan secara masinal akan langsung dibentuk sendiri oleh perajin menjadi benda-benda gerabah/keramik sampai pada tahap pembakaran, dan hasilnya bisa dibandingkan dengan keramik yang dibuat dengan tanah yang hanya diolah secara manual dan tradisional. Metode Eksperimen akan digunakan dalam rangka pemanfaatan tanah liat luar daerah dan tanah liat lokal yang dicampur menjadi bahan baku keramik. Beberapa pengujian sederhana akan dilakukan bersama perajin mitra. Metode Pendampingan digunakan dalam rangka mengontrol dan memantau perkembangan usaha yag dijalankan, membantu dalam hal pemasaran, khususnya membuatkan media internet secara online seperti Instagram, Facebook, blog, maupun media lainnya yang sesuai, serta memberikan motivasi dan semangat agar terus melanjutkan dan mengembangkan usahanya sampai semakin berkembang dan bisa menghasilkan produk yang lebih bermutu.

\section{HASIL DAN PEMBAHASAN}

3.1. Hasil

Hasil Pantauan awal sebelum pelatihan terlihat produk gerabah yang dibuat oleh mitra perajin masih banyak yang retak dan pecah, seperti observasi sebelumnya bahwa produk yang rusak pada saat di bakar mencapai 30\%. Sebagaimana solusi yang ditawarkan bahwa diperlukan kualitas tanah yang lebih baik yaitu tanah yang dihasilkan dengan teknik pengolahan secara masinal, namun berdasarkan diskusi terakhir dengan perajin, disepakati untuk tidak menggunakan mesin sebab dianggap terlalu rumit dan berat. Mitra menghendaki untuk mencoba lebih dahulu tanah dengan teknik saring basah, setelah itu diulek merata sampai plastis untuk dibentuk. 
imajinaasi

Pada tahap observasi awal ini juga dilakukan seleksi calon peserta pelatihan, sesuai kesepakatan dan hasil diskusi dengan mitra bahwa peserta pelatihan dibatasi saja jumlahnya maksimal 10 perajin, namun diharpakan betul-betul hasil pelatihan diterapkan untuk keperluan pembuatan produknya setelah kegiatan PKM. Melalui kesepakatan tersebut beberapa pertimbangan dijadikan kriteria sebagai peserta adalah bersedia menerapkan teknik penyaringan tanah liat setelah kegiatan PKM, bersedia bekerja sama dengan mitra dan tim PKM sampai tahap pendampingan. Terakhir bersedia meluangkan waktu untuk mengikuti pelatihan dan tidak menginggalkan tempat pelatihan sampai selesai tahap pembentukan.

Kegiatan pelatihan dilakukan selama dua hari yang diikuti oleh dua mitra dengan focus pada perajin laki-laki. Ada dua alas an mengapa perajin laki-laki, pertama sebab perajin laki-laki lebih terbuka terhadap perubahan dan bersedia mengubah cara dan pola kerja lama menjadi baru, kedua adalah perajin laki-laki pada umumnya lebih kreatif, namun jumlahnya masih sangat kurang khususnya di daerah Sandi. Pada awalnya target peserta adalah 10 orang, namun yang bersedia sesuai kesepakatan waktu hanya 7 orang, sehingga peserta hanya 7 orang.

Jumlah peserta disepakati untuk dibatasi sebab kegiatan pelatihan penyaringan diharapkan betul betul diterapkan setelah pelatihan, sehingga dapat bermanfaat untuk meningkatkan kualitas produk. Sebenarnya banyak perajin dari anggota mitra yang bersedia mengikuti pelatihan, namun tidak siap untuk menerapkan dan mencoba untuk menyaring tanahnya setelah pelatihan. Oleh sebab itu hanya 7 orang, namun ketujuh perajin tersebut bersedia mengikuti pelatihan dan menerapkan hasil pelatihanna di rumah masing-masing.

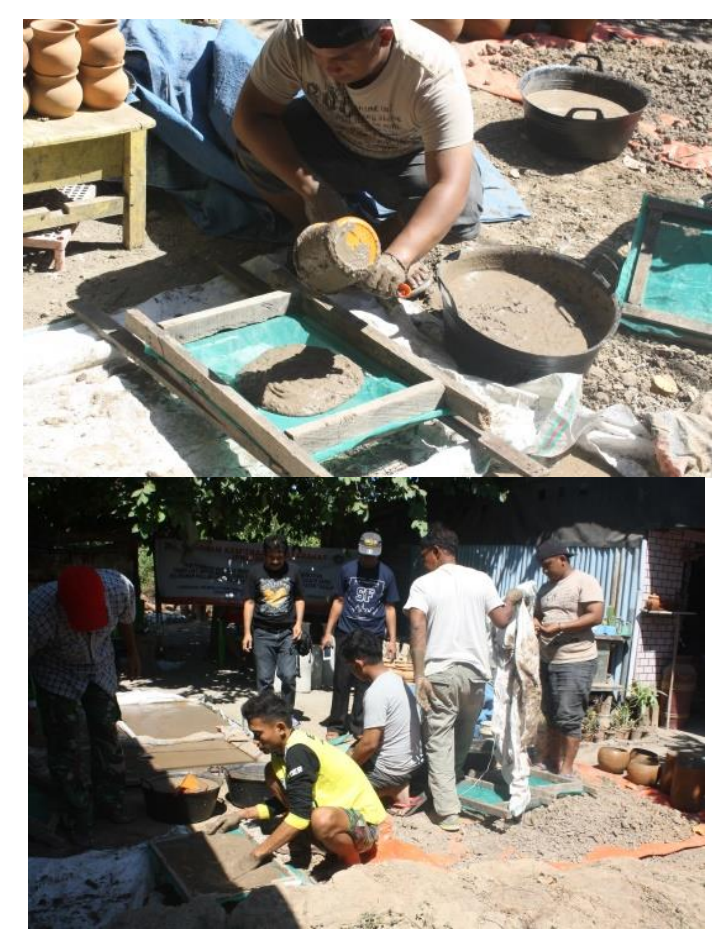

Gambar 2. Proses Pelatihan Menyaring Tanah.

Secara umum hasil pelatihan diuraikan dalam table sederhana dengan kategori nilai $10-100$. Nilai $10-60$ adalah kurang, $60-79$ cukup, $80-89$ bagus, dan 90 - 100 sangat bagus. Penentuan skor dilakukan dengan mempertimbangkan indicator pada setiap teknik yang dinilai, misalnya untuk teknik penguletan dilakukan dengan melihat tingkat plastisitas tanah yang telah diulek.

Tabel Hasil Pelatihan

\begin{tabular}{|l|l|c|c|c|}
\hline $\begin{array}{l}\text { N } \\
\text { o }\end{array}$ & Nama & $\begin{array}{c}\text { Penyari } \\
\text { ngan }\end{array}$ & $\begin{array}{c}\text { Pengul } \\
\text { etan }\end{array}$ & $\begin{array}{c}\text { Pembent } \\
\text { ukan }\end{array}$ \\
\hline 1 & $\begin{array}{l}\text { Yunus } \\
\text { Siama }\end{array}$ & 100 & 80 & 98 \\
\hline 2 & $\begin{array}{l}\text { Syams } \\
\text { unar } \\
\text { Sija }\end{array}$ & 100 & 80 & 98 \\
\hline 3 & $\begin{array}{l}\text { Muh. } \\
\text { Nur } \\
\text { Alam }\end{array}$ & 100 & 75 & 90 \\
\hline 4 & Ramli & 100 & 75 & 90 \\
\hline 5 & $\begin{array}{l}\text { Much } \\
\text { Iqbal }\end{array}$ & 100 & 75 & 80 \\
\hline 6 & Kaharu & 100 & 75 & 80 \\
\hline
\end{tabular}


Jalil, Irfan, Irfan Arifin: PENINGKATAN KUALITAS GERABAH MELALUI PENGOLAHAN DAN PENYARINGAN BAHAN DI SANDI KECAMATAN PATTALLASSANG KABUPATEN TAKALAR

\begin{tabular}{|c|l|c|c|c|}
\hline & ddin & & & \\
\hline 7 & $\begin{array}{l}\text { Abdul } \\
\text { Halim }\end{array}$ & 100 & 75 & 80 \\
\hline $\begin{array}{c}\text { Nilai Rata- } \\
\text { rata }\end{array}$ & 100 & 76 & 88 \\
\hline
\end{tabular}

Hasil pelatihan terhadap 7 orang perajin dari kelompok mitra menunjukkan bawa kemampuan perajin sangat baik dengan perolehan nilai 100. Sedangkan kemampuan dalam teknik penguletan berada dalam kategori cukup dengan perolehan nilai ratarata 76 . Teknik pembentukan berada pada kategori baik dengan nilai rata-rata 88. Dari ketiga materi pelatihan yang dilakukan pada umumnya seluruh peserta telah mampu menyaring dengan sempurna dengan nilai sangat baik sebab menyaring dengan cara manual prosesnya lebih mudah. Namun demikian, pada tahap teknik penguletan perajin masih belum maksimal sebab pada umumnya hasil penguletan belum plastis, terlihat dari hasil uji sederhana dengan mengetes hasil tanah yang telah diulet kebanyakan masih bergaris sebab penguleten belum merata, durasi waktu penguletan masih perlu ditambah oleh perajin. Pada tahap pembentukan, pada umumnya perajin sudah terampil membentuk, namun masih kurang dalam hal presisi dan penentuan ukuran dari bentuk yang dibuat.

\subsection{Pendampingan dan Evaluasi}

Setelah pelatihan berlangsung, dilanjutkan dengan pendampingan, dalam proses pendampingan ini, mitra akan diberikan peralatan yang dibutuhkan sesuai dengan kesepakatan dan masalah yang muncul saat proses pelatihan berlangsung, misalnya salah satu kendala yang dialami perajin adalah lamanya waktu yang dibutuhkan untuk mengeringkan tanah yang telah disaring, membutuhkan waktu antara 2-3 hari setelah disaring baru dapat diulek sebagai bahan siap pakai. Oleh sebab itu, maka untuk membantu mempercepat proses pengeringan, maka dibuatkan alat pengering terdiri dari lapisan bahan gipsun yang dapat menyerap air, sehingga lempung tanah saring yang diletakkan di atasnya lebih cepat kering.

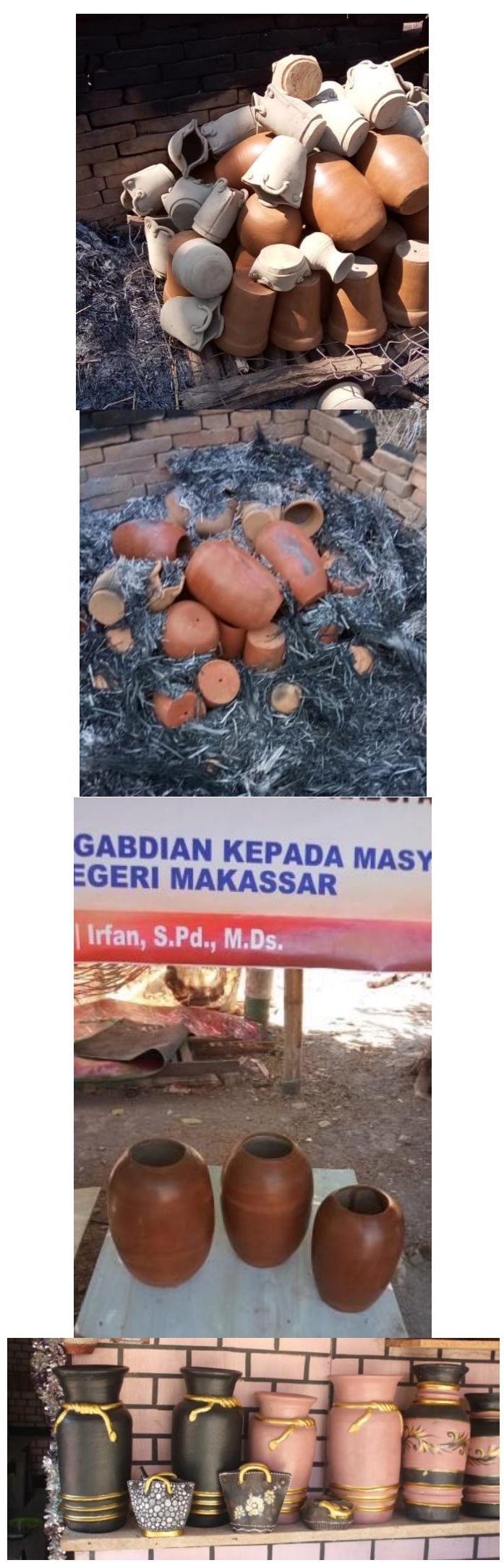

Gambar 3. Gerabah hasil pelatihan teknik saring dan olah bahan 
Tabel Hasil Pendampingan Pembakaran dan Hasil Pembakaran

\begin{tabular}{|c|l|c|c|c|}
\hline $\begin{array}{l}\text { N } \\
\text { o }\end{array}$ & Nama & $\begin{array}{c}\text { Pengering } \\
\text { an }\end{array}$ & $\begin{array}{c}\text { Pembakar } \\
\text { an }\end{array}$ & $\begin{array}{c}\text { Has } \\
\text { il }\end{array}$ \\
\hline 1 & $\begin{array}{l}\text { Yunus } \\
\text { Siama }\end{array}$ & 90 & 80 & 98 \\
\hline 2 & $\begin{array}{l}\text { Syamsun } \\
\text { ar Sija }\end{array}$ & 95 & 98 & 98 \\
\hline 3 & $\begin{array}{l}\text { Muh. } \\
\text { Nur } \\
\text { Alam }\end{array}$ & 95 & 85 & 99 \\
\hline 4 & Ramli & 80 & 85 & 99 \\
\hline 5 & $\begin{array}{l}\text { Much } \\
\text { Iqbal }\end{array}$ & 80 & 85 & 99 \\
\hline 6 & $\begin{array}{l}\text { Kaharud } \\
\text { din }\end{array}$ & 90 & 85 & 97 \\
\hline 7 & $\begin{array}{l}\text { Abdul } \\
\text { Halim }\end{array}$ & 95 & 85 & 97 \\
\hline \multicolumn{2}{|l|}{$\begin{array}{l}\text { Nilai Rata- } \\
\text { rata }\end{array}$} & 89 & 85 & 98 \\
\hline
\end{tabular}

Dari hasil pendampingan yang dilakukan terhadap proses pengeringan produk menunjukkan nilai rata-rata 89 atau kategori bagus dan mendekati sangat bagus. Pembakaran memperoleh nilai 85 dan masuk kategori bagus, sedangkan hasil pembakaran produk mencapai hasil yang sangat bagus disebabkan setiap pengrajin yang menggunakan tanah hasil penyaringan hasil produknya tidak ada yang mengalami keretakan. Gerabah ukuran sedang $10 \mathrm{~cm}-50$ $\mathrm{cm}$ yang dibuat dengan tanah saring 40 mesh terbukti tidak mengalami keretakan saat pembakaran. Sedangkan gerabah yang dibuat dari bahan tanah yang tidak disaring pada umumnya $30 \%$ mengalami keretakan dan pecah.

\section{KESIMPULAN DAN SARAN 4.1. Kesimpulan}

Dari ketiga materi pelatihan yang dilakukan pada umumnya seluruh peserta telah mampu menyaring dengan sempurna dengan nilai sangat baik sebab menyaring dengan cara manual prosesnya lebih mudah. Namun demikian, pada tahap teknik penguletan perajin masih belum maksimal sebab pada umumnya hasil penguletan belum plastis, terlihat dari hasil uji sederhana dengan mengetes hasil tanah yang telah diulet kebanyakan masih bergaris sebab penguleten belum merata, durasi waktu penguletan masih perlu ditambah oleh perajin. Pada tahap pembentukan, pada umumnya perajin sudah terampil membentuk, namun masih kurang dalam hal presisi dan penentuan ukuran dari bentuk yang dibuat.

Dari hasil pendampingan yang dilakukan terhadap proses pengeringan produk menunjukkan nilai rata-rata 89 atau kategori bagus dan mendekati sangat bagus. Pembakaran memperoleh nilai 85 dan masuk kategori bagus, sedangkan hasil pembakaran produk mencapai hasil yang sangat bagus disebabkan setiap pengrajin yang menggunakan tanah hasil penyaringan hasil produknya tidak ada yang mengalami keretakan. Gerabah ukuran sedang $10 \mathrm{~cm}-50$ $\mathrm{cm}$ yang dibuat dengan tanah saring 40 mesh terbukti tidak mengalami keretakan saat pembakaran. Sedangkan gerabah yang dibuat dari bahan tanah yang tidak disaring pada umumnya $30 \%$ mengalami keretakan dan pecah.

\subsection{Saran}

Tanah yang telah disaring masih perlu diuji pada pembuatan gerabah dengan ukuran besar antara $60 \mathrm{~cm}$ sampai $150 \mathrm{~cm}$ untuk lebih menguatkan asumsi bahwa tanah yang telah disaring jauh lebih baik.

\section{UCAPAN TERIMA KASIH}

Terima kasih kepada Direktorat Riset dan Pengabdian Masyarakat Direktorat Jenderal Riset dan Pengembanga Ristek Dikti atas program PKM, terima kasih kepada Rektor Universitas Negeri Makassar, Ketua LPPM UNM, Dekan FSD UNM, Ketua Jurusan Seni Rupa dan Desain FSD UNM, kedua mitra yang terlibat (Yunus dan Syamsunar) serta seluruh Tim PKM.

\section{DAFTAR PUSTAKA}

Sudiyati, Noor, "Keramik Singkawan Kalimantan Barat, Kajian Aspek Estetika" Disertasi Doktor Universitas Gajah Mada, Yogyakarta, 2012. H. 10 
Jalil, Irfan, Irfan Arifin: PENINGKATAN KUALITAS GERABAH MELALUI PENGOLAHAN DAN PENYARINGAN BAHAN DI SANDI KECAMATAN PATTALLASSANG KABUPATEN TAKALAR

BPS, Kabupaten Takalar Dalam Angka 2015, Takalar: Badan Pusat Statistik, 2015. H. 179

Irfan, Keramik Takalar, Kesinambungan, Perubahan dan Model Pengembangannya, Disertasi Doktoral Program Pascasarjana Institut Seni Indonesia Surakarta, 2018. H. 60

Astuti, Ambar, Keramik, Ilmu dan Proses Pembuatannya, Yogyakarta: Program SPMA Fakultas Seni Rupa Institut Seni Indonesia Yogyakarta kerjasama dengan Arindo Nusa Media, 2008. H. 5. 